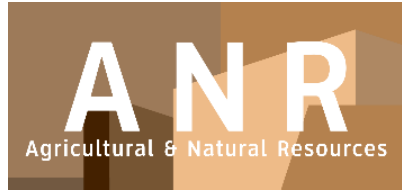

PAPER - OPEN ACCESS

Uji Nutrisi Dadih Susu Kerbau dan Susu Kambing dengan Menggunakan Bambu Ampel (Bambusa vulgaris) dan Bambu Gombong (Gigantochloa verticilata)
Author
: F.C. Harahap
DOI
: 10.32734/anr.v1i2.234
Electronic ISSN
: 2654-7023
Print ISSN
: 2654-7015

Volume 1 Issue 2-2018 TALENTA Conference Series: Agricultural \& Natural Resources (ANR)

his work is licensed under a Creative Commons Attribution-NoDerivatives 4.0 International License.

Published under licence by TALENTA Publisher, Universitas Sumatera Utara
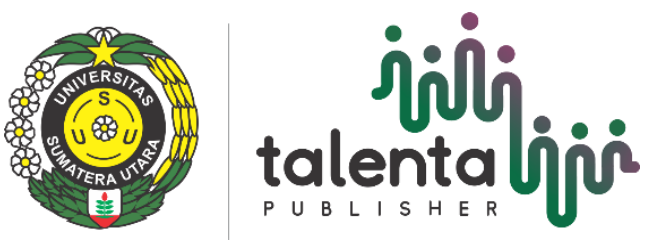


\section{iji} talentalioio TALENTA Conference Series

Available online at https://talentaconfseries.usu.ac.id

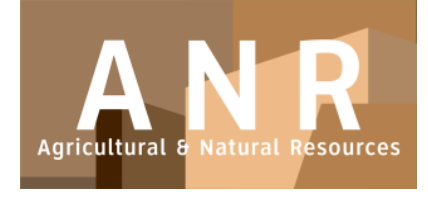

\title{
Uji Nutrisi Dadih Susu Kerbau dan Susu Kambing dengan Menggunakan Bambu Ampel (Bambusa vulgaris) dan Bambu Gombong (Gigantochloa verticilata)
}

\author{
F.C. Harahap ${ }^{a *}$, N. Ginting1, Hamdan ${ }^{\mathrm{a}}$, A. H. Daulay ${ }^{\mathrm{a}}$, Hasnudi $^{\mathrm{a}}$ \\ Program Studi Peternakan Fakultas Pertanian, Universitas Sumatera Utara, Medan 20155, Indonesia
}

\author{
fujichairunnisa@gmail.com
}

\begin{abstract}
Abstrak
Penelitian ini bertujuan untuk mengetahui kandungan nutrisi dadih susu kerbau dan dadih susu kambing dengan menggunakan Bambu Ampel (Bambusa Vulgaris) dan Bambu Gombong (Gigantochloa verticilata). Penelitian ini dilaksanakan di Laboratorium Teknologi Pangan Fakultas Pertanian Universitas Sumatera Utara pada bulan Mei - Juli 2017. Rancangan yang dipakai dalam penelitian ini adalah rancangan acak lengkap pola faktorial menggunakan dua faktor yaitu faktor susu (S): (S1/ susu kerbau dan S2/ susu kambing) dan faktor kedua bakteri (B): (B1/ tanpa menggunakan Bambu, B2/ menggunakan Bambu Gombong, B3/ menggunakan Bambu Ampel). Parameter yang dianalisis yaitu Protein, Lemak, dan pH. Hasil penelitian menunjukkan bahwa dadih susu kerbau dan dadih susu kambing dengan menggunakan Bambu Ampel dan Bambu Gombong memberikan pengaruh yang berbeda nyata $(\mathrm{F}>0,05)$ terhadap nilai nutrisi lemak dan $\mathrm{pH}$ serta tidak berbeda nyata $(\mathrm{F}<0,05)$ terhadap nilai nutrisi protein. Dari ketiga nilai nutrisi yang diteliti diperoleh hasil tertinggi dari dadih susu kerbau menggunakan Bambu Gombong dengan rataan protein: faktor susu 5.7815 dan faktor bakteri 5.8463, rataan lemak: faktor susu 8.1610 dan faktor bakteri 8.8136, rataan $\mathrm{pH}$ : faktor susu 5.6781 dan faktor bakteri 5.5178. Dari analisis nutrisi protein, lemak dan $\mathrm{pH}$ diketahui bahwa pengolahan dadih yang terbaik adalah susu kerbau dengan menggunakan Bambu Gombong (Gigantochloa Verticilata).
\end{abstract}

Kata Kunci: Type your keywords here, separated by semicolons ;

\section{Pendahuluan}

Banyak produk olahan susu fermentasi yang dikenal seperti yoghurt, kefir, es krim, keju, dan mentega, Terdapat juga produk olahan susu fermentasi tradisional yang sudah lama dikenal dan disukai oleh masyarakat seperti di Sumatera Barat dari bahan dasar susu kerbau atau biasa dikenal dengan dadih yang dapat di konsumsi. Dadih merupakan makanan tradisional yang terbuat dari susu kerbau yang difermentasikan di dalam bambu. Dadih juga merupakan produk olahan susu yang menyerupai yogurt dan kefir. Pengolahan dadih di Sumatera Barat umumnya banyak dijadikan sebagai lauk pauk.

Di Sumatera Barat, susu kerbau diolah menjadi dadih yang dimakan dengan gula aren. Cara membuat dadih adalah susu disimpan selama 2 hari dalam tabung bambu sampai serum susu dan gumpalan bekuan susu (dadih) terpisah. Di Aceh susu kerbau diolah menjadi minyak samin (mentega). Caranya susu didiamkan selama 24 jam dalam ember atau belanga untuk memisahkan kepala susu dengan serum susu. Kepala susu kemudian diuapkan 
airnya, sehingga diperoleh campuran lemak dan bekuan protein susu. Campuran ini kemudian disaring untuk dipisahkan lemak (mentega, minyak samin) dengan bekuan protein susu [2].

Dadih Sumatera Barat dibuat dengan bahan dasar susu kerbau dengan mengandalkan jasad renik yang ada di alam sebagai inokulan tanpa menggunakan starter tambahan. Para peternak melakukan pengolahan dadih seperti yang dilakukan secara turun menurun tanpa mengalami perbaikan teknik pengolahannya. Pada dasarnya dadih termasuk produk fermentasi seperti kefir dan yoghurt [4].

Fermentasi dalam pembuatan dadih mengandalkan jasad renik yang ada di alam sebagai inokulum. Mikroba tersebut diperkirakan berasal dari tabung bambu sebagai wadah [9], dapat juga dari daun pisang penutup tabung atau dari susu itu sendiri [8].

Proses fermentasi dilakukan pada suhu kamar selama 24-48 jam. Dadih berwarna putih dan bentuknya mirip tahu yang dapat dipotong. Dadih dikonsumsi langsung dengan memakai sendok ataupun diolah. Pada umumnya dadih dimanfaatkan sebagai lauk pauk, makanan selingan, pelengkap upacara adat dan sebagai obat-obatan tradisional [5].

Proses pembuatan dadih yaitu persiapan bambu, pemerahan dan proses terjadinya dadih. Bambu yang digunakan adalah jenis bambu gombong (Gigantochioa verticilate) dan bambu ampel (Bambusa vulgaris). Jenis bambu tersebut dipilih karena rasanya pahit sehingga tidak disukai semut. Selanjutnya dadih ditutup daun talas, daun pisang, plastik maupun tanpa penutup [3].

Bambu gombong mempunyai buluh berwarna hijau kekuning-kuningan dengan garis-garis kuning yang sejajar dengan buluhnya. Bambu ini memiliki keunggulan yaitu daya serap airnya tinggi. Bambu ampel merupakan bambu yang umumnya dimiliki oleh warga sehingga bambu ini juga sering dipakai dalam pembuatan dadih karena tidak perlu membeli. Selain itu, keunggulan dari kedua jenis bambu ini adalah keduanya memiliki rasa pahit sehingga dapat menghindarkan semut [3].

Kandungan nutrisi dadih bervariasi, bergantung pada daerah produksinya. Menurut Sirait dan Setiyanto [4], dadih mengandung air $82,10 \%$, protein $6,99 \%$, lemak $8,08 \%$, keasaman $13,15^{\circ} \mathrm{D}$, dan $\mathrm{pH} 4,99$. Kandungan laktosa dadih $5,29 \%$, pH 3,4 serta daya cerna protein cukup tinggi (86,4-97,7\%). Dadih mengandung 16 asam amino (13 asam amino esensial dan tiga asam amino nonesensial) sehingga dapat menjadi makanan bergizi yang mudah diserap tubuh, dan vitamin A1, 70-7,22 IU/g [8].

Pada penelitian ini pengolahan dadih dapat dibuat dari bahan dasar susu kerbau dan susu kambing yang akan dituangkan ke dalam tabung bambu selama \pm 24 jam sampai 2-3 hari sehingga terjadi fermentasi spontan yang akan meningkatkan mutu dan cita rasa dadih. Fermentasi pada dadih memiliki bambu, daun pisang dan susu kerbau dan susu kambing. Setelah terjadi fermentasi yang spontan pada dadih, peneliti akan menganalisikan uji nutrisi dari protein susu, lemak susu dan tingkat keasaman $(\mathrm{pH})$ susu pada dadih susu kerbau dan dadih susu kambing dengan menggunakan bambu ampel dan bambu gombong. Juga peneliti akan menganalisi uji nutrisi protein susu, lemak susu, tingkat keasaman $(\mathrm{pH})$ susu pada dadih susu kerbau dan dadih susu kambing tanpa menggunakan bambu.

Atas dasar latar belakang di atas maka peneliti tertarik untuk melakukan penelitian tentang uji nutrisi dalam pengelolahan dadih susu kerbau dan dadih susu kambing dengan menggunakan dua jenis bambu yang sering digunakan oleh masyarakat Sumatera Barat dalam mengelolah dadih yang akan meningkatkan mutu nutrisi dan cita rasa pada dadih.

\section{Bahan dan Metode}

\subsection{Lokasi Penelitian}

Penelitian dilaksanakan di Laboratorium Teknologi Hasil Pangan Departemen Ilmu dan Teknologi Pangan Fakultas Pertanian Universitas Sumatera Utara. 


\subsection{Metode}

Penelitian ini dilaksanakan pada bulan Mei- Juli 2017. Adapun bahan yang digunakan dalam penelitian ini adalah susu kerbau dan susu kambing segar sebagai bahan objek penelitian ; dua jenis bambu yaitu bambu gombong dan bambu ampel segar sebagai tempat pembuatan dadih; daun pisang sebagai penutup ujung pada bambu saat melakukan fermentasi serta bahan kimia (K2SO4, CuSO4, $\mathrm{NaOH}, \mathrm{H} 2 \mathrm{SO} 4$, Indicator mengsel, heksan) dalam menganalisis protein, lemak dan $\mathrm{pH}$. Adapun alat yang digunakan adalah gergaji untuk memotong bambu; kompor untuk memanaskan susu; thermometer untuk mengukur suhu susu pada saat dipanaskan; sutil untuk mengaduk susu pada saat dipanaskan; sendok sebagai alat pengambil dadih dari dalam bambu; baskom sebagai tempat pembuatan dadih: tabung reaksi sebagai tempat uji biokimia; pipet sebagai alat mengambil cairan dengan jumlah tertentu; gelas ukur digunakan untuk pengukuran volume tidak tahan panas; mikropipet untuk mengambil cairan dibawah sebanyak $1 \mathrm{ml}$ yaitu 200-1000 mikroliter; kertas label sebagai alat tulis penanda; dan kamera sebagai alat dokumentasi. Penelitian ini menggunakan Rancangan Acak Lengkap (RAL) Faktorial dengan 2 faktor yaitu faktor 1 (Susu dengan 2 level) dan faktor 2 (Bakteri dengan 3 level) 6 perlakuan dan 3 ulangan. Adapun perlakuan sebagai berikut : S1 (Susu Kerbau), S2 (Susu Kambing), B1 (Tanpa menggunakan Bambu), B2 (menggunakan Bambu Gombong), B3 (menggunakan Bambu Ampel).

\section{Hasil}

Pada penelitian ini parameter yang diamati adalah protein, lemak dan $\mathrm{pH}$

\subsection{Protein Dadih Susu Kerbau dan Dadih Susu Kambing}

Data yang diperoleh dari penelitian untuk nilai kadar protein dadih susu kerbau dan dadih susu kambing menggunakan bambu gombong dan bambu ampel dapat dilihat pada grafik.

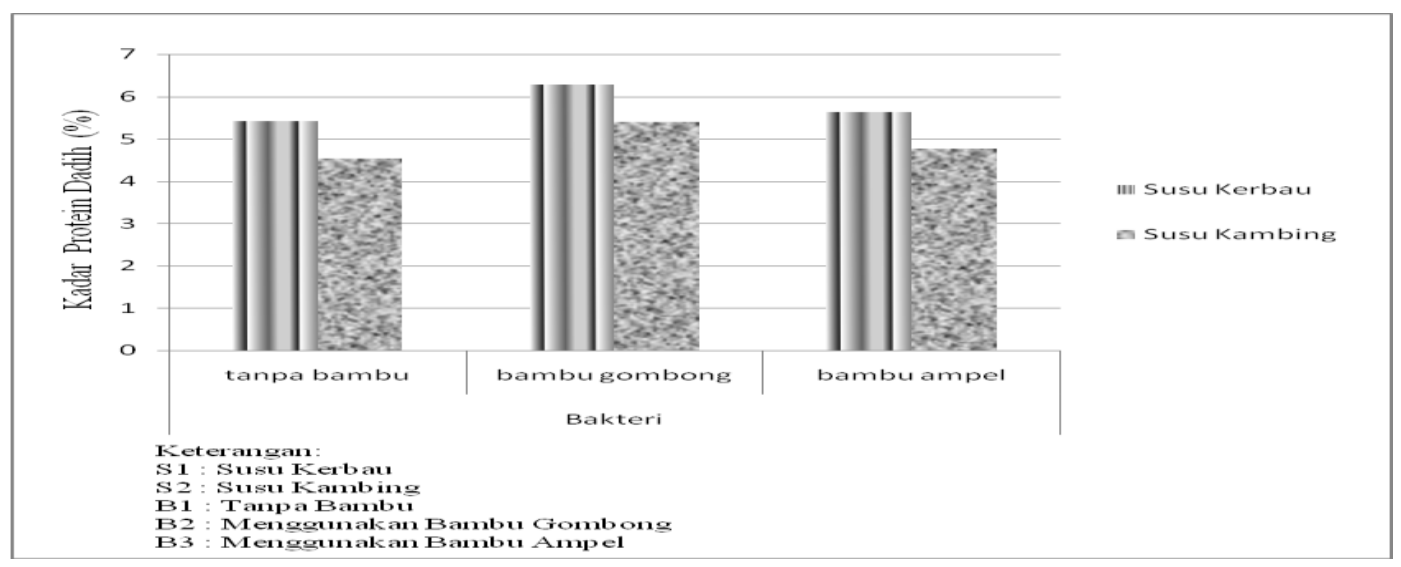

Gambar. 1. Grafik kadar protein dadih susu kerbau dan dadih susu kambing dengan menggunakan Bambu Gombong dan Bambu Ampel.

Berdasarkan grafik diatas rata-rata kadar protein dadih susu kerbau dan dadih susu kambing menggunakan bambu gombong dan bambu ampel pada faktor susu di peroleh rataan tertinggi terdapat pada perlakuan S1 (Susu kerbau) yaitu sebesar 5.7815 sedangkan rataan kadar protein dadih susu kerbau dan dadih susu kambing menggunakan bambu gombong dan bambu ampel terendah terdapat pada perlakuan S2 (susu kambing) yaitu sebesar 4.9068. Kadar protein dadih susu kerbau dan susu kambing menggunakan bambu gombong dan bambu ampel pada bakteri diperoleh rataan tertinggi terdapat pada perlakuan B2 (menggunakan bambu gombong) yaitu sebesar 5.8463 sedangkan rataan protein dadih susu kerbau dan dadih susu kambing menggunakan bambu gombong dan bambu ampel terdapat pada perlakuan B1 (tanpa menggunakan bambu) yaitu sebesar 4.9823. 


\subsection{Lemak Dadih Susu Kerbau dan Dadih Susu Kambing}

Data yang diperoleh dari penelitian untuk nilai kadar lemak dadih susu kerbau dan dadih susu kambing menggunakan bambu gombong dan bambu ampel dapatdilihat pada grafik.

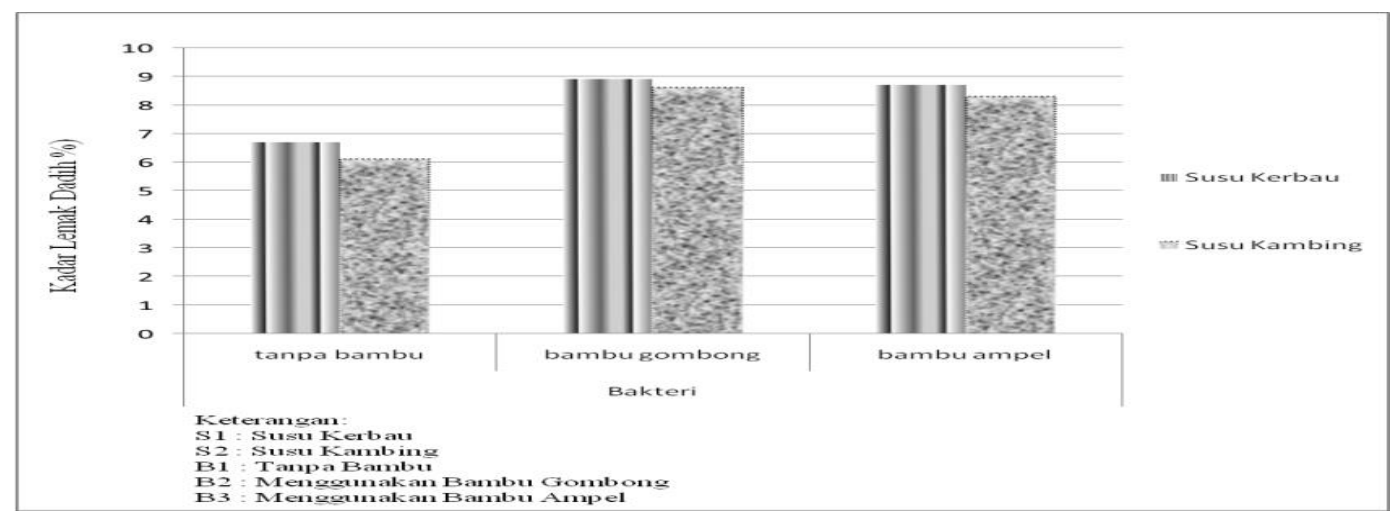

Gambar. 2. Grafik kadar lemak dadih susu kerbau dan dadih susu kambing dengan menggunakan Bambu Gombong dan Bambu Ampel.

Berdasarkan grafik diatas rata-rata kadar lemak dadih susu kerbau dan dadih susu kambing menggunakan bambu gombong dan bambu ampel pada faktor susu di peroleh rataan tertinggi terdapat pada perlakuan S1 (Susu kerbau) yaitu sebesar 8.1610 sedangkan rataan kadar lemak dadih susu kerbau dan dadih susu kambing menggunakan bambu gombong dan bambu ampel terendah terdapat pada perlakuan S2 (susu kambing) yaitu sebesar 7.7010. Kadar lemak dadih susu kerbau dan susu kambing menggunakan bambu gombong dan bambu ampel pada bakteri diperoleh rataan tertinggi terdapat pada perlakuan B2 (menggunakan bambu gombong) yaitu sebesar 8.8136 sedangkan rataan lemak dadih susu kerbau dan dadih susu kambing menggunakan bambu gombong dan bambu ampel terdapat pada perlakuan B1 (tanpa menggunakan bambu) yaitu sebesar 6.4247 .

\section{3. pH Dadih Susu Kerbau dan Dadih Susu Kambing}

Data yang diperoleh dari penelitian untuk nilai $\mathrm{pH}$ dadih susu kerbau dan dadih susu kambing menggunakan bambu gombong dan bambu ampel dapat dilihat pada grafik.

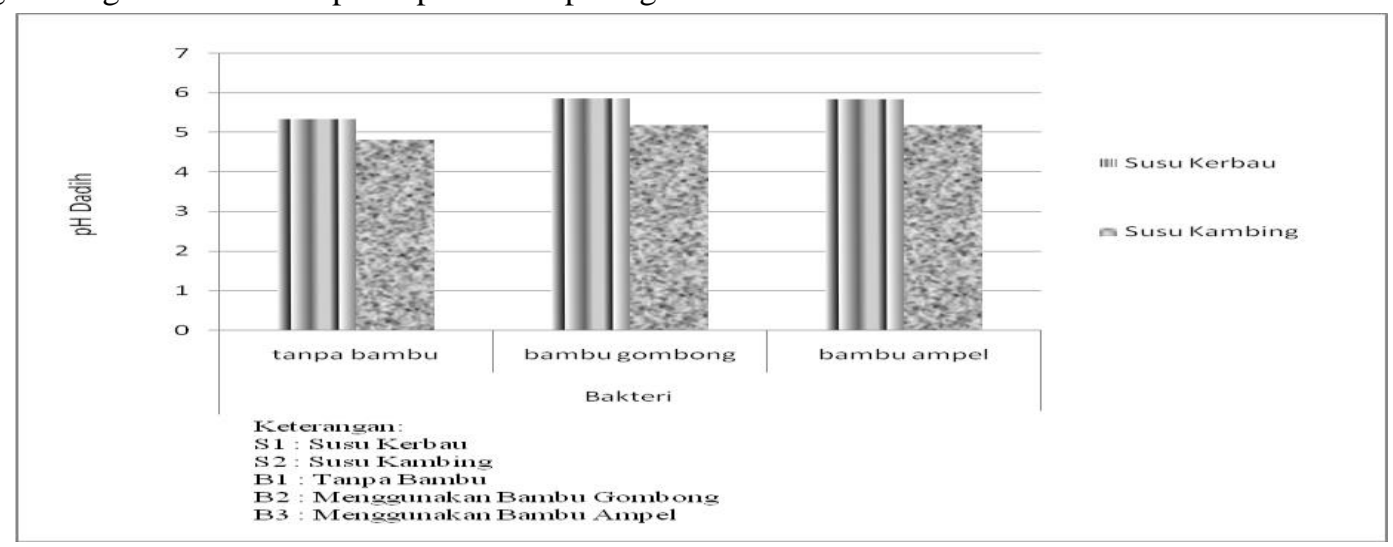

Gambar. 3. Grafik pH dadih susu kerbau dan dadih susu kambing dengan menggunakan Bambu Gombong dan bambu ampel.

Berdasarkan grafik di atas. rata-rata nilai $\mathrm{pH}$ dadih susu kerbau dan dadih susu kambing menggunakan Bambu Gombong dan Bambu Ampel pada faktor susu di peroleh rataan tertinggi terdapat pada perlakuan S1 (Susu kerbau) yaitu sebesar 5.6781 sedangkan rataan nilai $\mathrm{pH}$ dadih susu kerbau dan dadih susu kambing menggunakan bambu 
gombong dan bambu ampel terendah terdapat pada perlakuan S2 (susu kambing) yaitu sebesar 5.0571. Nilai pH dadih susu kerbau dan susu kambing menggunakan Bambu Gombong dan Bambu Ampel pada bakteri diperoleh rataan tertinggi terdapat pada perlakuan B2 (menggunakan Bambu Gombong) yaitu sebesar 5.5180 sedangkan rataan lemak dadih susu kerbau dan dadih susu kambing menggunakan Bambu Gombong dan Bambu Ampel terdapat pada perlakuan B1 (tanpa menggunakan Bambu) yaitu sebesar 5.0775.

\section{Pembahasan}

Tingkat kadar protein akan berbeda pada penggunaan bambu yang berbeda- beda dalam pembuatan dadih susu kerbau dan dadih susu kambing yang akan mempengaruhi nilai kadar protein yang di tentukan dengan kualitas susu sehingga akan menyebabkan protein pada susu menggumpal menjadi asam. Hal ini sesuai dengan pernyataan Karmana [1], yang menyatakan bahwa fermentasi pada susu biasanya dilakukan oleh bakteri Streptococcus dan Lactobacillus, yang akan merombak laktosa menjadi asam laktat. Berarti semakin lama pemeraman asam laktat yang terbentuk akan semakin banyak dan $\mathrm{pH}$ akan turun karena suasana menjadi asam, yang akan menyebabkan protein pada susu (kasein) menggumpal.

Peningkatan kadar lemak dadih dipengaruhi oleh adanya aktivitas sejumlah bakteri asam laktat dalam pembuatan dadih susu kerbau dan dadih susu kambing dengan menggunakan bambu gombong dan bambu ampel sehingga dapat mengubah lemak menjadi asam lemak dan gliserol. Hal ini sesuai dengan pernyataan Wahyuni [7] yang menyatakan bahwa kadar lemak dapat meningkat karena adanya aktivitas sejumlah bakteri dalam bambu terdapat bakteri asam laktat yaitu Lactobacillus sp, sehingga kandungan lemak pada dadih pun akan meningkat karena bakteri tersebut dapat membentuk asam lemak dan gliserol.

Penggunaan bambu yang berbeda dalam pembuatan dadih akan memberikan pengaruh terhadap nilai $\mathrm{pH}$ dadih. Hal ini sesuai dengan pernyataan Taufik [6] yang menyatakan Perubahan nilai $\mathrm{pH}$ dadih dipengaruhi oleh aktivitas dan jumlah bakteri asam laktat dalam pembuatan dadih susu kerbau dan dadih susu kambing. Semakin lama waktu penyimpanan akan semakin menurunkan nilai $\mathrm{pH}$ dadih tersebut. Komponen susu yang berperan dalam fermentasi adalah laktosa dan kasein. Laktosa digunakan sebagai sumber energi dan karbon yang nantinya akan diubah oleh BAL menjadi asam laktat. Asam laktat tersebut menyebabkan keasaman dadih dalam peningkatan atau penurunan nilai $\mathrm{pH}$.

\section{Kesimpulan dan Saran}

Dari analisis nutrisi protein, lemak, dan $\mathrm{pH}$ diketahui bahwa pengolahan dadih yang terbaik susu kerbau dengan menggunakan bambu gombong (Gigantochloa Verticilata).

Untuk pengembangan penelitian selanjutnya disarankan meneliti jumlah populasi mikroorganisme pada setiap ruas bambu baik dari dadih yang memakai bambu gombong ataupun bambu ampel.

\section{Ucapan Terima Kasih}

Saya mengucapan terima kasih kepada Program Studi Peternakan yang telah memfasilitasi atau berkontribusi pada pelaksanaan penelitian saya.

\section{Referensi}

[1] Karmana, O. 2007. Cerdas Belajar Biologi. Bandung: Grafindo Media Pratama

[2] Rukmana R. 2003. Beternak Kerbau Potensi dan Analisis Usaha. Aneka Ilmu. Semarang.

[3] Sayuti, K. 1992. Studi Nilai dan Konsumsi Makanan Tradisional Dadih di Sumatera Barat Studi Kasus di Kecamatan Lembah Gumanti. Program Pascasarjana Gizi Masyarakat dan Kesehatan Keluarga. Insitut Pertanian Bogor

[4] Sirait, CH., H. Setiyanto, Triyantini dan R. Sunarlim, 1994. Evaluasi mutu dadih. Prosiding Seminar Sain dan Teknologi Peternakan. Pengelolahan dan Komunikasi Hasil-hasil Penelitian. Buku I. Ciawi-Bogor 25-26 Januari 1994. Balai Penelitian Ternak, Ouslitbangnak, Litbang Pertanian. Hal: 275-280 
[5] Sugitha, I.M. dan Aidi, L.A. 1998. Daya cerna dadih yang dibuat dengan penambahan starter Streptococus Lactis dalam tabung plastik. Jurnal Peternakan dan Lingkungan Vo. 4. No. 03:60-64.

[6] Taufik, E. 2004. Dadih Susu Sapi Hasil Fermentasi berbagai Starter Bakteri Probiotik yang Disimpan pada Suhu Rendah: Karakteristik Kimiawi. Media Peternakan, 27 (3) : 88-100

[7] Wahyuni, Sri. 2009. Uji Kadar Protein dan Lemak pada Keju Kedelai dengan Perbandingan Inokulum Lactobacillus Bulgaricus dan Streptococcus Lactis yang Berbeda. Skripsi. Program Studi Pendidikan Biologi, Fakultas Keguruan dan Ilmu Pendidikan Biologi. Surakarta: Universitas Muhammadiyah Surakarta.

[8] Yudoamijoyo, R.M., T. Zoelfikar, S.R. Herastuti, A. Tomomatsu, A. Matsuyama, and A. Ozono. 1983. Chemical and micro-biological aspect of dadih in Indonesia. Japanese J. Dairy Food Sci. 32(1): 1-10.

[9] Zakaria, Y., H. Ariga, T. Urashima, and T. Toba. 1998. Micro-biological and rheological properties of the Indonesian traditional fermented milk dadih. Milchwisschaft 53: 30-33. 